\title{
Ocher Containers and Trade in the Central Mediterranean Copper Age
}

\author{
LAURA MANISCALCO
}

\begin{abstract}
Recent excavations at Serra del Palco, near Milena, in south-central Sicily north of Agrigento, have led to the discovery of a group of small jars belonging to the first phase of the Copper Age (San Cono-Piano Notaro-Grotta Zubbia Phase). The jars held ocher and were buried in small pits. They testify to ritual practices and identify this class of jars specifically as ocher containers. In addition they provide important evidence of prehistoric contacts between Sicily and Malta. On Malta potters of the Zebbug Culture employed ocher, most probably imported from Sicily, and Zebbug pottery reflects influence from San Cono-Piano Notaro-Grotta Zubbia wares, which may have been transmitted, at least in part, by ocher jars like those from Serra del Palco.*
\end{abstract}

Pottery production, and especially prehistoric pottery production, is usually studied from a stylistic or technological point of view. It is rare that discussion faces the question of the use and function of various classes of pottery. It is true that adequate information for this purpose is frequently lacking, but a series of unusual discoveries made during excavation at Serra del Palco presents the opportunity of asking just such questions with respect to pottery of the San ConoPiano Notaro-Grotta Zubbia class of the the Sicilian Early Copper Age. ${ }^{1}$ In addition this material points to the existence of commercial contacts between Sicily and the Maltese islands during the third millennium B.C.

Serra del Palco is a bare ridge projecting toward the southwest from Monte Campanella near the village of Milena north of Agrigento (fig. 1). In a level area below the serra recent excavations have brought to light a Neolithic village of the Stentinello phase, which is distinctive because of the remains of heavy

\footnotetext{
* I am grateful to V. La Rosa for having entrusted me with the publication of the Early Copper Age material from the excavations in the area of Milena by the University of Catania in collaboration with the Soprintendenza archeologica per la Sicilia centro meridionale. This article is based on material included in this larger study. I further wish to thank R. Ross Holloway of Brown University for undertaking the translation of my Italian text. The drawings are by C. Catanzaro.

${ }^{1}$ On the Copper Age in Sicily (third millennium B.C.) see L. Bernabò Brea, "Considerazioni sull'eneolitico e sulla prima età del bronzo della Sicilia e della Magna Grecia," Kokalos 14-15 (1968-1969) 20-58. S. Tiné, "Gli scavi nella
}

enclosure walls. ${ }^{2}$ Some traces of a curving wall also testify to the existence of a later settlement belonging to the Late Copper Age. No structures of the Early Copper Age have been identified. The San ConoPiano Notaro-Grotta Zubbia pottery at the site frequently comes from unstratified contexts. There are four cases, however, in which vases, both intact and fragmentary, have been found. They come from as many as three pits dug into the chalk formation underlying the site. ${ }^{3}$

At the westernmost edge of the southern Neolithic enclosure five small San Cono-Piano Notaro-Grotta Zubia vases, in fragmentary condition, were found in one such pit. The cavity was roughly circular in shape $(0.86 \times 0.81 \mathrm{~m})$. The fragments of pottery were found resting on a prominent stratum of ocher while remains of carbonized seeds were noted on the side walls of the pit. Apparently, the vases filled with ocher and perhaps also with seeds were deposited in the pit. The pottery from this first pit is as follows:

SR PL 85/387. Rim fragment and lower portion of a jar. Irregular floor of interior coated with ocher. Incised and dotted line at point of maximum diameter, below this an incised eye. Gray, well fired, and hard clay; worn surface, also gray. Base dia. $5 \mathrm{~cm}$, wall thickness $0.5 \mathrm{~cm}$, ht. $7.5 \mathrm{~cm}$ (fig. 2).

SR PL 85/388. Lower half of a biconical jar. Irregular floor of interior coated with ocher. At point of maximum diameter, an incised line, below which four dot rosettes spaced about $9 \mathrm{~cm}$ apart. Incisions filled with a white substance. Gray clay, surface black with reddish patches. Base dia. ca. $5 \mathrm{~cm}$, th. $0.4-0.5 \mathrm{~cm}$, ht. ca. $5 \mathrm{~cm}$ (fig. 3 ).

SR PL 85/389. Fragments of the base and body of a vessel of indefinite shape. Interior floor flat and irregular. On the

Grotta della Chiusazza," BPI 74, N.S. 16 (1965) 123-286. A. Cazzella, "Considerazioni su alcuni aspetti eneolitici dell'Italia meridionale e della Sicilia," Origini 6 (1972) 171-298. On the San Cono-Piano Notaro-Grotta Zubia style see B.E. McConnell, San Cono-Piano Notaro-Grotta Zubbia Ceramics in Sicilian Prehistory (Diss. Brown University 1985).

${ }^{2}$ V. La Rosa, "Un nuovo insediamento neolitico a Serra del Palco di Milena (CL)," Atti della XXVI riunione scientifica dell'Istituto Italiano di Preistoria e Protostoria, Firenze 1985 (1987) 801-808.

${ }^{3}$ La Rosa (supra n. 1) fig. 1. 


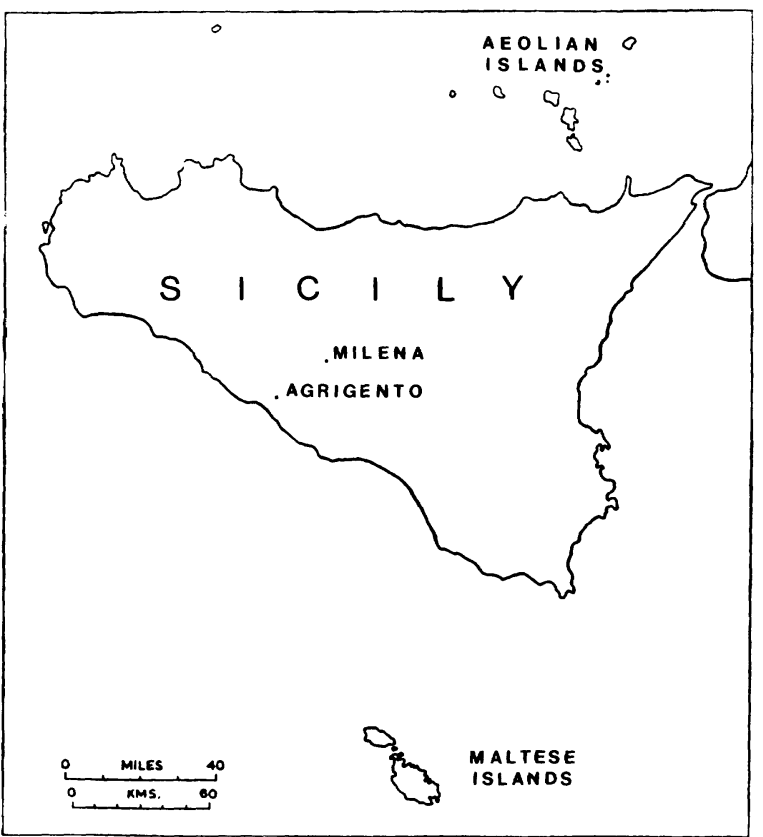

Fig. 1. Map of Sicily and the Maltese islands, with sites mentioned in the text

body an incised eye with incrustations of a whitish substance. Black clay, worn surface. Th. $0.4 \mathrm{~cm}$.

SR PL 85/482. Body fragments of a vessel of indefinite shape. On the body a rosette of impressed dots. Black clay. Gray, worn surface; reddish patches on the exterior. Th. 0.5 cm.

SR PL 85/483. Fragments of the rim and body from a vessel of closed form, possibly a jar. Fine black clay. On one body fragment a double horizontal line. Rim dia. ca. $12 \mathrm{~cm}$, th. $0.3 \mathrm{~cm}$.

A second pit, $3 \mathrm{~m}$ south of the first and measuring $0.76 \times 0.67 \mathrm{~m}$ was fortunately preserved even though it had been cut through by a large fissure in the underlying chalk. It contained two miniature vases placed on a bed of ocher and themselves filled with the same substance.

SR PL 85/155. Jar with swelling ovoid body. Coarse clay, well baked, dark gray, the surface polished shiny gray. Incised decoration: a horizontal line just below the lip filled with red ocher and a series of dots just above the point of maximum diameter filled with a white substance. Surface spotted with red ocher. The vase contained red ocher dust. Ht. $5.0 \mathrm{~cm}$, rim dia. $4.5 \mathrm{~cm}$ (figs. 4, 6).

SR PL 85/156. Bowl with carinated profile and incurving lip. Clay and surface as the preceding. Incised decoration: horizontal line beneath the lip filled with red ocher, a series of impressed dots also filled with a white substance. Surface spotted with red ocher. The vase contained red ocher dust. Ht. $3.0 \mathrm{~cm}$, rim dia. $6.0 \mathrm{~cm}$ (figs. 5,6 ).

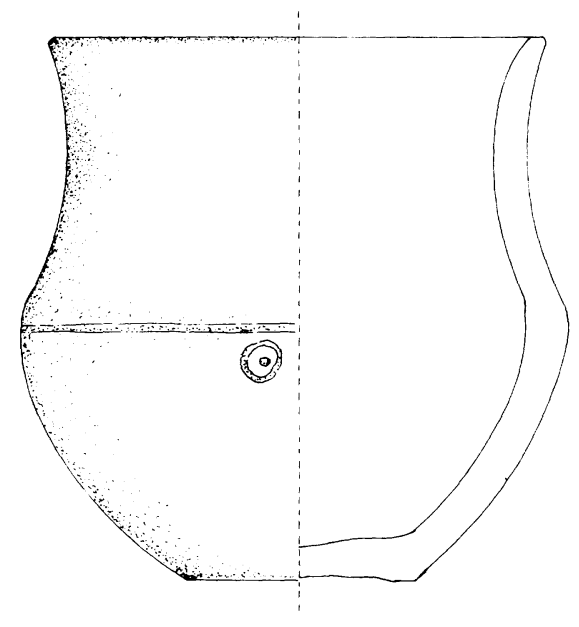

Fig. 2. SR PL $85 / 387$, from the first pit at Serra del Palco $(1: 2)$

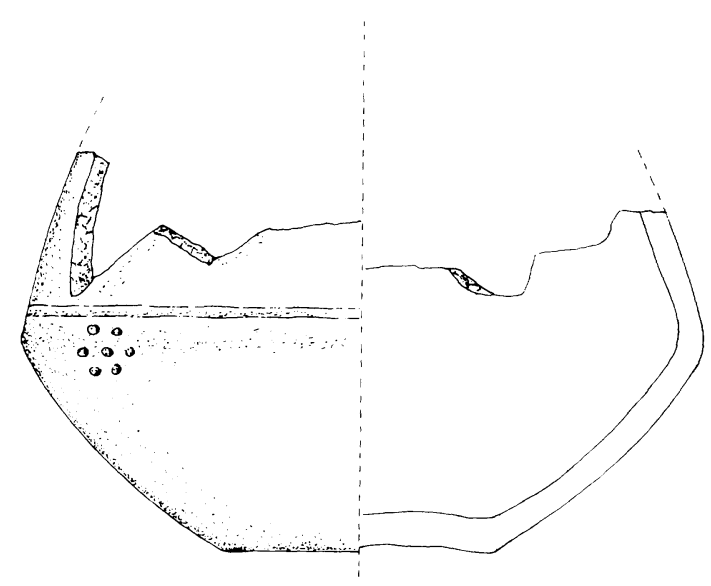

Fig. 3. SR PL $85 / 388$, from the first pit at Serra del Palco $(1: 2)$

In a third pit at some distance from the first two, three fragments of San Cono-Piano Notaro-Grotta Zubbia pottery were found in association with a small red rim fragment and several chips of flint and obsidian. At the bottom of the pit were traces of burning.

SR PL 85/443. Body fragment. Dark gray clay, well baked, polished gray surface. Exterior incised decoration: double segmented line with traces of red ocher. The interior also with spots of red ocher. Th. $0.6 \mathrm{~cm}$.

SR PL 85/445. Curved lip, slightly outturning, from a closed shape. Coarse fabric with gray core and dark red interior. Clear gray-red exterior surface. Exterior surface polished and decorated with an incised eye slightly below the lip from which radiate horizontal and vertical lines. Traces of red ocher in the incisions. Th. $0.8 \mathrm{~cm}$. 


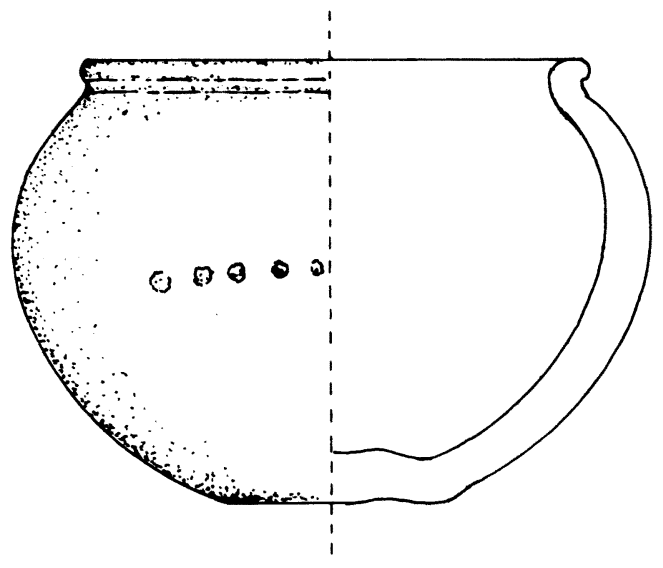

Fig. 4. SR PL 85/155, from the second pit at Serra del Palco (1:1)

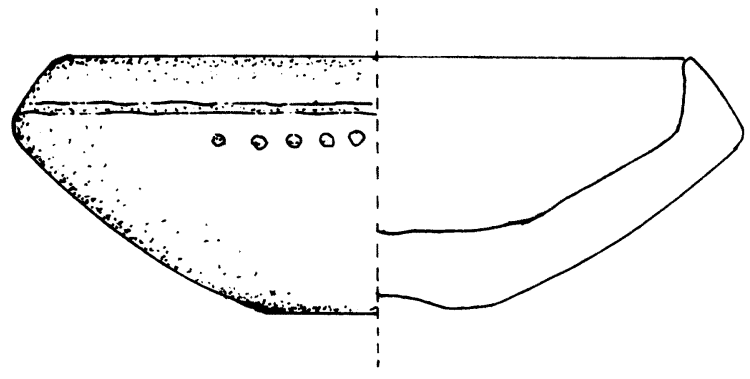

Fig. 5. SR PL 85/156, from the second pit at Serra del Palco (1:1)

SR PL 85/446. Fragment of rounded lip. Dark red clay, surface polished to a clear dark red. Double horizontal incised line slightly below the lip. Th. $0.7 \mathrm{~cm}$.

SR PL 85/444. Small slightly everted lip. Gray-red clay, well baked, surface polished to a strong red. Th. $0.9 \mathrm{~cm}$.

Parallels for the shapes and especially for the decorative patterns of these vases may be found in westcentral Sicily. ${ }^{4}$

\footnotetext{
${ }^{4}$ The shape and the decoration of the miniaturistic jar SR PL 85/155 is known in the Conca d'Oro complex (J. BovioMarconi, "La cultura della Conca d'Oro della Sicilia nordoccidentale," MonAnt 60 [1944] 1-170, pls. 9.12, 4.4. F. Quoiani, "Indagini nella necropoli di Capaci. Nuovi aspetti locali e loro connessioni con la cultura della Conca d'Oro," Origini 9 [1975] 225-71, fig. 17.7) and in central Sicily at Marianopoli (G. Fiorentini, "Ricerche archeologiche nella Sicilia centromeridionale," Kokalos 26-27 [19801981] 581-600, pl. 68.2. A small bowl of the same type as SR PL 85/156 also occurs in the necropolis of contrada Tranchina near Sciacca (McConnell [supra n. 1] fig. 22). The motifs of the dot rosette and the eye flanked by a partly solid, partly dotted line occur in the necropolis of contrada Tranchina and in the Conca d'Oro complex as well (Mc-
}

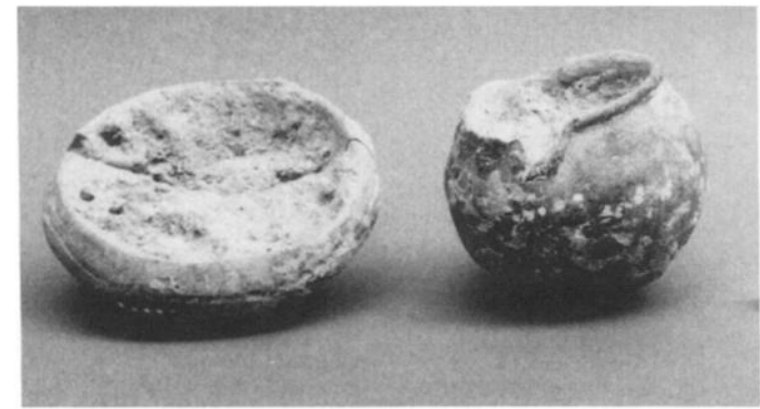

Fig. 6. SR PL $85 / 156$ and $85 / 155$, from the second pit at Serra del Palco (1:2)

It is possible that other vases and fragments of the San Cono-Piano Notaro-Grotta Zubbia style bearing notable traces of red ocher on their bodies, but found without significant context during the excavation of the Neolithic village at Serra del Palco, may actually come from pits such as those described above. Two other pits, again containing vases but without traces of ocher, have been discovered during the most recent excavation campaigns.

Both in the Early Copper Age of the Italian peninsula and elsewhere, vases placed in pits have been found, even if infrequently, in settlements and in caves. In the cave of S. Angelo at Civitella del Tronto, near Teramo, a pit was excavated which contained a vase covered with a stone slab. ${ }^{5}$ There is an even closer parallel to be found at the settlement of Piscina di Torre Spaccata near Rome, which belongs to the Rinaldone Culture. ${ }^{6}$ Found there were three trench pits with pottery, faunal remains, and charcoal. At the megalithic complex in Aosta a bell beaker had been broken in two and the parts buried in two pits. This find has been interpreted as evidence of a foundation ritual. ${ }^{7}$ The trench pit at Torre Spaccata may be compared with the third pit at Serra del Palco. Both may

Connell [supra n. 1] figs. 7, 21. S.M. Cassano and A. Manfredini, "Scavi nella necropoli di Uditore e prospettive di inquadramento cronologico delle più antiche facies della Conco d'Oro," Origini 9 [1975] 153-217, fig. 16.4-5). The four vases from the first pit are homogeneous in style and were probably made by the same potter. The same homogeneity is apparent in the two vases from the second pit.

${ }^{5}$ A. Radmilli, "Dal paleolitico all'età del bronzo," Popoli e civiltà dell'Italia antica 1 (Rome 1974) 392.

${ }^{6}$ A.M. Bietti Sestieri and A. Gianni, "L'abitato di Piscina di Torre Spaccata (Roma)," poster at the international congress L'età del rame in Europa, Viareggio, 15-18 October 1987.

${ }^{7}$ D. Burroni and F. Mezzena, "Megalitismo ed arte rupestre in Italia settentrionale durante l'Eneolitico," paper 
be simple refuse pits. In the case of the first two pits at Serra del Palco, however, whole vases were intentionally filled with ocher and placed in the pits.

What interpretation can be offered for the two pits at Serra del Palco? Possibly they represent a supply of ocher put away for later use, but the small vessels involved could not have held any great quantity of the substance. Furthermore, such an explanation does not account for the presence of seeds in the pits.

The stratum of ocher on the floor of the pits and the use of this type of small jar immediately call to mind the assemblages of the contemporary chamber-tombs of the period (tombe a pozzetto) which are documented in Sicily, especially in the west-central part of the island. ${ }^{8}$ The absence, however, of any skeletal remains and the dimensions of the pits themselves exclude the possibility that they might have been tombs. But could it be that these are symbolic tombs or cenotaphs? Although theoretically admissible, such a notion is foreign to what one might expect for the Copper Age and is unsupported by any even remote parallels. A more logical explanation would see these pits in a ritual context. This line of thought finds some support in the placement of the pits. They are, in fact, positioned at the edge of the large southern Neolithic enclosure wall, while the two additional pits discovered during recent work at the site are situated on the west side of the northern enclosure. All four of these

read at the international congress L'età del rame in Europa, Viareggio, 15-18 October 1987.

${ }^{8}$ For vases filled with ocher in tomb groups, see M.O. Acanfora, "Ocra rossa e decoraziona incisa su une olletta preistorica di Palermo," AttiPal 5 (1946) 154-62. Quoiani (supra n. 4) 234 and Cassano and Manfredini (supra n. 4) $158,162,164$. For ocher covering the floor of tombs see G. Castellana and F. Mallegni, "The Prehistoric Settlement of Piano Vento in the Territory of Palma di Montechiaro (Agrigento, Italy)," Archivio per l'antropologia e l'etnologia 116 (1986) 61-80. The single parallel outside funerary contexts is a red-surfaced vessel from Grotta Zubbia which was found filled with red ocher but in an unrecorded context (unpublished, Museo Regionale Archeologico di Agrigento). Two lumps of red ocher were found at Serraferlicchio: P.E. Arias, "La stazione preistorica di Serraferlicchio presso Agrigento," MonAnt 36 (1938) 693-838, esp. 816.

9 On the "culture of the enclosure" in Sicilian prehistory and protohistory, see the paper by E. De Miro on the excavations of Polizello, together with the following comments from the floor, at the VII Congresso internazionale di studi sulla Sicilia antica, Palermo, May 1988, forthcoming. One must emphasize, however, that at Serra del Palco although the enclosure built in the Neolithic was treated with respect, as shown by the pits studied here, during the Early Copper Age, there is no evidence for occupation during the late Neolithic Diana phase. pits, therefore, appear to have been intentionally placed along the perimeter of the Neolithic enclosures. One may thus advance a hypothesis not dissimilar to that already entertained for the pits at Aosta with this difference: at Milena the purpose of the pits seems to have been to recall the presence of earlier structures from the Neolithic period, no longer functional but still visible above ground, while at Aosta the purpose was apparently to make a foundation deposit. Seen in this perspective, the absence of any evidence for habitation during the Early Copper Age in the immediate vicinity of the Neolithic enclosures, and the presence of Copper Age pits at Serra del Palco may well indicate that the area was subject to ritual avoidance (abaton or religiose saeptum in later Greek and Roman parlance). ${ }^{9}$ One may conclude, therefore, that ocher not only played a part in funerary ritual but could also be included with seeds or fruits in a ritual offering. ${ }^{10}$

Naturally, the association of ocher and vessels of the San Cono-Piano Notaro-Grotta Zubbia style is not limited to Serra del Palco. There are many instances in which vases of this class show traces of ocher, not only as filling material of incised decoration but on the interior as well. ${ }^{11}$ Thus it is possible that some closed forms of San Cono-Piano Notaro-Grotta Zubbia pottery were intended specifically as containers of ocher. ${ }^{12}$ In view of the magical and therapeutic prop-

${ }^{10}$ In habitations of the French Palaeolithic, ocher was spread inside the huts, especially near hearths. This usage has been interpreted as a rite of consecration by Escalo de Fonton, "Un campement de chasseurs de rennes près du Pont du Gard," ArcheologiaPar 6 (1965) 20-21. However, a functional view of the matter is advanced by A. Leroi-Gourhan and M. Brezillon, "Fouilles de Pincevent (la section 36)," Gallia Préhistoire, Suppl. 7 (1972) 89-93. For carbonized seeds in pits see the Grotta di S. Angelo at Civitella del Tronto, Radmilli (supra n. 5) 501.

${ }^{11}$ Material from the Grotta I of Fontanazza and from M. Conca near Milena.

${ }^{12}$ At Uditore the ocher was found in cups and especially in small jars, Cassano and Manfredini (supra n. 4) fig. 16.1, $16.2 ; 19.2 ; 21.3$. At Capaci it was found in a one-handled mug, Quoiani (supra n. 4) fig. 17.3 and at Serra del Palco in jars and bowls. Other forms of the San Cono-Piano NotaroGrotta Zubbia repertoire suggest other functions. For example the jars with perforated ledge handles with indentations on their edges, corresponding to the Classical pyxis, could have been containers for volatile substances calling for a tightly sealed lid. It is perhaps not without significance that these pyxis-jars are found almost exclusively in tombs. See McConnell (supra n. 1) CAG 117 (Mpisu), CAG100, CAG110 (Tranchina). Cassano and Manfredini (supra n. 4) figs. 19.1, 19.5. At Piano Vento tombs of transitional Neolithic-Copper Age date held similar jars with painted 
erties attributed to this substance,,$^{13}$ there exists the possibility that some of the decoration found on vases of the San Cono-Piano Notaro-Grotta Zubbia style from the area of Milena was apotropaic. This is certainly true of the serpent ornament of the handle of a cup from Grotta I of Fontanazza near Milena. The relation of the serpent to chthonian cults needs no elaboration, but apotropaic associations may also exist for the human face covered with ocher on a rim from Contrada S. Paolino in the same district.

The relationship between ocher and pottery of the San Cono-Piano Notaro-Grotta Zubbia style also has bearing on the problem of connections between this pottery and the Maltese pottery of the Zebbug phase, a problem which has major significance for the study of the development of the Copper Age cultures of the central Mediterranean. The Zebbug Culture represents a decisive break with earlier traditions of Maltese pottery that reach back to the Neolithic. The new Zebbug ceramic style is strikingly similar to San Cono-Piano Notaro-Grotta Zubbia pottery. One reaction to such

decoration; see G. Castellana, "Il villaggio neolitico di Piano Vento nel territorio di Palma di Montechiaro," Atti della seconda giornata di studi sull'archeologia licatese e della zona della bassa valle dell'Himera (Licata 1985) 9-67, pl. 25.3.

${ }^{13}$ D. Schmandt-Besserat, "Ocher in Prehistory: 300,000 Years of the Use of Iron Ores as Pigments," in T.A. Wertime and J.D. Muhly eds., The Coming of the Age of Iron (New Haven 1980) 127-50. J. Velo, "Ochre as Medicine: A Suggestion for the Interpretation of the Archaeological Record," Current Anthropology 25:5 (1984) 674.

${ }^{14}$ D. Trump, "Contatti siculo-maltesi prima dell'età del bronzo," Kokalos 22-23 (1976-1977) 23-32. McConnell (supra n. 1) 52 for the elements common to the two styles.

${ }^{15}$ D. Trump, Skorba (Oxford, 1966) 49.

${ }^{16}$ J.D. Evans, "Archaeological Evidences for the Religious Practices in the Maltese Islands during the Neolithic and Copper Ages," Kokalos 22-23 (1976-1977) 130-45.

${ }^{17}$ J.G. Baldacchino and J.D. Evans, "Prehistoric Tombs near Zebbug, Malta," BSR 22 (1954) 1-21. In Tombs 3 and 4 the ocher was found in a cup with handle, and possibly in a shallow bowl. J.D. Evans, The Prehistoric Antiquities of the Maltese Islands (London 1971) 112. At Xemxija in certain tombs of a slightly later period (Ggantija) the lowest stratum appeared to be impregnated with red ocher (Tomb 3) and the incised decoration of some vases is gener- similarity might be to suggest that immigrants from Sicily brought the style to Malta. ${ }^{14}$ But one must also consider another element vital in this discussion: the Maltese need for ocher. Ocher is not found on the Maltese islands, ${ }^{15}$ but it was a substance which must have been almost indispensable for the ceremonies which appear to have been characteristic of the Copper Age on Malta. ${ }^{16}$ It was used, for example, in Maltese funerary ritual, which, as can be seen from the tombs of Zebbug and Xemxija, was remarkably similar to that practiced in Sicily. ${ }^{17}$ It is therefore quite probable that ocher was imported from nearby Sicily, where it was available, and that it came to Malta in its characteristic containers, vases of the San Cono-Piano NotaroGrotta Zubbia style. Evidently, in addition to their interest in the contents, the Maltese also developed a taste for the style of the containers, and this led to the creation of the Zebbug style of pottery, different from but based on Sicilian prototypes.

VIA ALCIDE DE GASPERI, 24I

CATANIA 95127, ITALY

ously filled with the same material (Tombs 3 and 5). Ocher, however, is not found in Copper Age tombs of the Italian peninsula. See P.C. Sestieri, "La necropoli preistorica di Paestum," Atti del I congresso internazionale di preistoria e protostoria mediterranea (Rome 1950) 195-200. G. Voza, "Ultimi scavi della necropoli del Gaudo," Atti della IX riunione scientifica dell'Istituto Italiano di Preistoria e Protostoria (1964-1965) 265, and "Necropoli del Gaudo," Seconda mostra della preistoria e della protostoria nel Salernitano (Salerno 1974) 7-24. G. Bailo Modesti, "Eboli, necropoli eneolitica," Seconda mostra (supra) 25-42. R.R. Holloway, Buccino. The Eneolithic Necropolis of S. Antonio and Other Prehistoric Discoveries made in 1968 and 1969 by Brown University (Rome 1973). G.A. Colini, "Il sepolcreto di Remedello di sotto nel bresciano e il periodo eneolitico in Italia," BPI 28 (1902) 5-43. F. Rittatore, "Scoperte dell'età eneolitica e del bronzo nella Maremma tosco-laziale," Rivista di scienze preistoriche 6 (1951) 3-33. F. Biancofiore, "La necropoli eneolitica di Laterza," Origini 1 (1967) 195300. In the necropoleis of Sgurgola di Anagni, which belong to the Rinaldone phase, cinnabar takes the place of ocher for the treatment of the dead and their tomb goods: L. Pigorini, "Tombe dell'età della pietra scoperte nella provincia di Roma," BPI 6 (1880) 8-13. For other references to the Copper Age in peninsular Italy, see A.M. Radmilli, Guida alla preistoria italiana (Milan 1978). 